\title{
Diz çevresi osteotomileri; komplikasyonlar, komplikasyonlardan korunma ve çözümleri
}

\author{
Osteotomies around the knee; complications, prevention, and solutions \\ Mahmut Nedim Doral ${ }^{1}$, Gökhan Ayık², Doğaç Karagüven ${ }^{1}$ \\ ${ }^{1}$ Ufuk Üniversitesi Tıp Fakültesi Ortopedi ve Travmatoloji Anabilim Dalı, Ankara \\ ${ }^{2}$ Bayburt Devlet Hastanesi, Ortopedi ve Travmatoloji Kliniği, Bayburt
}

Diz çevresi düzeltici osteotomileri, diz ekleminin yapısını göreceli olarak korur. Bu nedenle oldukça dikkat isteyen girişimlerdir. Günümüzde, tespit teknikleri ile bundan önce yaşanmış sorunlar ve komplikasyonların aza indirilmiş olması memnuniyet vericidir. Ancak, yine de diz çevresi düzeltici osteotomi sürecinin her basamağında komplikasyonlar görülebilmektedir. Her durumda hasta seçiminin çok önem taşıdığı bir gerçektir. Doğru seçim, detaylı ameliyat öncesi (preoperatif) değerlendirme, doğru plan, doğru teknik ve kullanilacak implantlar, deneyimli cerrahlar, titiz bir ameliyat sonrası (postoperatif) bakım, doğru ve hastaya özel rehabilitasyon programları sonuçların yüz güldürücü olmasına neden olmakta, komplikasyon riskini azaltmaktadır. Günümüzde, geniş ölçüde kabul gören bir kılavuz rehber, hasta seçimi değerlendirme kılavuzu veya risk faktör analizi bildirimleri bulunmamaktadır. Bu durum literatüre şüphe ve dikkatle yaklaşmayı gerektirse de geçmişten günümüze geldiğimiz nokta memnuniyet verici ve dikkat çekicidir.

Anahtar sözcükler: osteotomi; diz eklemi; komplikasyonlar
Osteotomies around the knee are quite remarkable interventions due to their relative preservation of the structure of the knee joint. It is gratifying that the problems and complications experienced in the past have been reduced with the surgeon's experience and the current fixation techniques and implants. Nevertheless, we can still encounter complications at every step of the osteotomy process around the knee. At this point, patient selection is very important. When selection of the appropriate patient, a detailed preoperative evaluation, a valid plan, experienced surgeons, a good technique, and rigorous postoperative care and rehabilitation programs are combined with experience, good results are achieved and complications are reduced. Today, there are no widely accepted guidelines or patient selection guides or risk factor analyses of these procedures. Although this situation requires a suspicious approach to literature, the level that we have reached from the past to the present is remarkable.

Key words: osteotomy; knee joint; complications
A It ekstremite mekanik aksı (ekseni), diz ekleminin kıkırdak yüzeylerinin aşınma durumu için önemlidir. Tarihsel süreçte diz çevresi osteotomileri, özellikle unikompartmantal diz osteoartritinin tedavi yöntemlerinden biri olmuştur. Fakat artroplastideki güncel gelişmeler ve yeni implantlar, osteotomiye olan ilgiyi azaltmaktaydı. Son yıllarda eklemin doğal durumunu korumak, gelecekteki olası artroplasti seçeneğini geciktirmek veya önlemek amacıyla unikompartmantal kondral patolojisi ve mekanik uyumsuzluğu olan genç hastalarda diz çevresi osteotomilerine olan ilgi tekrar artmıştır. Dizde varus deformitesi, osteoartritte en sık görülen mekanik dizilim bozukluğudur. ${ }^{[1]}$ Alt ekstremitede varus dizilimi olduğu zaman ise yük anormal şekilde medial tibiofemoral kompartmandan iletilmekte ve kıkırdak, subkondral kemik ve medial menisküste anormal bir strese neden olmaktadır. ${ }^{[2]}$ Genelde medialden başlayan diz osteoartriti adeta bir kısır döngü halinde eklemin tamamına yayılmaktadır. Yüksek tibial osteotomi (YTO) ise bu kısır döngüyü, yükü lateral kompartmana kaydırarak kırma şansına sahiptir. Böylelikle dejenerasyonun önüne geçilmeye çalışılır. ${ }^{[3]}$

YTO'nun temel olarak üç yöntemi vardır;

- Kapalı kama,

- Açık kama,

- Kubbe yani "dome” osteotomisi. ${ }^{[4]}$

- Illetişim adresi: Prof. Dr. Mahmut Nedim Doral, Ufuk Üniversitesi Tıp Fakültesi Ortopedi ve Travmatoloji Anabilim Dalı, Ankara Tel: 0532 - 2120785 e-posta: mndoral@gmail.com

- Geliş tarihi: 20 Ocak 2020 Kabul tarihi: 19 Șubat 2020 
Kapalı kama YTO ilk olarak Jackson ve Waugh tarafından 1961 yılında tanımlanmış ve sonrasında 1965 yılında Coventry tarafından popülarize edilmiştir. ${ }^{[5]}$ YTO'da başarı ise genellikle artroplastiye dönüş ile ölçülmektedir. Uygun hasta seçimi, iyi bir plan ve teknik, öğrenme süreci ve cerrahi deneyim hem sonuçları hem de komplikasyonları etkileyen önemli faktörlerdir. ${ }^{[3]}$

YTO'nun en sık endikasyonu, medial gonartroz ile birlikte olan varus dizlerdir. ${ }^{[3]}$ Valgus deformiteler ise görece olarak daha az sıklıkta görülmekte ve literatürü de göreceli olarak daha az olmaktadır. Fakat bu deformite sonucunda zaman içerisinde lateral menisküs ve kondral hasarın oluştuğu literatürde gösterilmiştir. ${ }^{[6]}$ iddiopatik genu valgum, sıklıkla hipoplastik lateral femoral kondilden kaynaklanmaktadır. Bu nedenle tedavide eklem çizgisini paralel hale getirecek ve iyatrojenik bir eklem çizgi oblikliği yaratmayacak distal femoral osteotomiler (DFO) tercih edilen tedavi metotlarındandır. Valgus deformitesinde distal femoral osteotomiler, lateral açık kama veya medial kapalı kama tekniği ile yapılabilmektedir. ${ }^{[1]}$

YTO ve DFO gibi diz çevresi osteotomiler, sadece unikompartmantal diz osteoartriti olanlarda değil, genç hastalarda osteokondral lezyon ve eklem instabilitesi gibi durumların tedavisinde de uygun hasta seçimi ve endikasyon ile uygulanabilmektedir. Diz çevresi osteotomilerin her basamağında komplikasyon görülebilmektedir. Bu nedenle iyi sonuç alınabilmesi ve komplikasyonların önlenebilmesi için cerrahi adayın uygun olarak seçimi ve risk faktörlerinin titizlikle araştırılması önem arz etmektedir. ${ }^{[7]}$

Yukarıda da bahsedildiği gibi diz çevresi osteotomiler günümüzde sadece unikompartmantal osteoartritte uygulanmamaktadır. Distal femoral varus osteotomisi, dizilim bozukluğunu tedavi etmenin yanında kıkırdak restorasyon cerrahisi yapılmış (osteokondral veya menisküs allogrefti) diz kompartmanını korumak amacı ile de yapılabilir. ${ }^{[8]}$ Menisküs transplantasyonu yapılan dizlerde, dizilimi sağlamanın yanı sıra ilgili kompartmanı korumak maksadı ile de diz çevresi osteotomiler prosedüre eklenebilir. ${ }^{[9]}$ Willey ve ark., 35 adet en az bir yıllık takibi olan DFO veya YTO'ya ek olarak kıkırdak yüzey yenileme, bağ rekonstrüksiyonu, menisküs transplantasyonu, rekonstruktif ekstensör mekanizma dizilim cerrahisi vb. uygulanmış popülasyonda komplikasyonları araştırmışlar. Sonuç olarak kombine prosedürlerin komplikasyon oranını izole osteotomiler ile benzer bulmuşlar. Ancak cerrahi plan, teknik ve rehabilitasyon için hasta uyumunun oldukça önemli olduğunu da vurgulamışlar. ${ }^{[10]}$
Stride ve ark.'nın yaptıkları bir derlemede, eş zamanlı yapılan YTO ve ön çarpraz bağ (ÖÇB) rekonstrüksiyonlarını incelemişlerdir. Komplikasyon oranlarının $\% 0-23,5$ arasında olduğunu saptamışlar, en sık görülen üç komplikasyonu da; inatçı ağrı ve eklem hareket açıklığında kısıtlanma, derin ven trombozu ve gerektiğinde implant çıkarımı şeklinde sıralamışlardır. ${ }^{[11]}$

Geçmişten günümüze yeni tespit cihazlarının ortaya çıkması implant başarısızlığı, korreksiyon (düzeltme) kaybı gibi komplikasyonlarda azalma ile sonuçlanmış ve son dönemlerde osteotomilere tekrar ilginin artmasına neden olmuştur. Yeni tespit cihazları ile hastalara daha erken yük verdirme mümkün olmakta ve iyileşme daha hızlı meydana gelmektedir. Böylelikle uzun süreli immobilizasyonlara gerek kalmamaktadır. Tüm gelişmelere rağmen osteotomilere bağlı komplikasyonlar, sonuçları ve hasta memnuniyetini engelleyen ana faktör olarak orada durmaktadır. ${ }^{[7]}$ Ameliyat öncesi (Preoperatif) kötü bir plan ve hasta seçiminde yapılan yanlışlıklar hem komplikasyonların ortaya çıkmasına hem de fonksiyonel olarak kötü bir sonuca neden olmaktadır. ${ }^{[12]}$ Lateral kapalı kama YTO tarihsel olarak tercih edilen metot olmuştur. Son yıllarda ise fibular osteotomi gerektirmeyen açık kama YTO daha benimsenir hale gelmiştir. Bu durumun başlıca nedenleri olarak erken rehabilitasyon şansı, nörovasküler komplikasyon riskinin azalması ve klasik kapalı kama osteotomisine göre artroplastiye dönüşün daha kolay olması şeklinde sayılabilir. Bunun yanı sıra, açık kama YTO'da patella infera, yaratılan kemik boşluk nedeniyle kaynamama, gecikmiş kaynama gibi komplikasyonlar görülebilmektedir. ${ }^{[13]}$

Genel olarak bakıldığında diz çevresi osteotomilerin en sık komplikasyonları şu şekilde özetlenebilir[7];

- Kortikal menteşe bölgesinde ya da eklem içine uzanan (intraartiküler) kırıklar

- Beklenmeyen aşırı veya yetersiz düzeltmeler

- İmplant başarısızlığı

- Bölgesel ağrı sendromları

- Gecikmiş kaynama veya kaynamama

- Nörovasküler yaralanma

- Enfeksiyon

Cerrahiye uygun hastanın seçimi gerek sonuçların iyi olması gerekse de komplikasyonlardan kaçınmak için oldukça önemlidir. Trieb ve ark. 65 yaş altı hastalarda daha az başarısızlık oranı bildirmiştir. ${ }^{[14]}$ Genel kanının aksine Floerkemeier ve ark. ise yaş ve sonuçlar arasında bir korelasyon görememiştir. ${ }^{[15]}$

ISAKOS (International Society of Arthroscopy, Knee Surgery and Orthopedic Sports Medicine), 2005 yilında YTO için uygun hasta seçimini içeren ve geniş kabul 
gören bir protokol yayımlamıştır. Bu protokol ile YTO için ideal hastalar, olası hastalar ve uygun olmayan hastalar belirlenmiştir. Zamanla bu protokolde bazı değişimler olsa da temel olarak ideal bir YTO hasta adayını şu şekilde tanımlayabiliriz; izole medial eklem ağrısı bulunan, vücut kitle indeksi (VKi) $<30 \mathrm{~kg} / \mathrm{m}^{2}$, dizilim bozukluğu $<15^{\circ}$, tibial kemik varus açısı $>5^{\circ}$, tam eklem hareket açıklığı olan, lateral ve patellofemoral kompartmanları normal, ligamentöz instabilitesi olmayan, sigara içmeyen aktif, beklentisi olan, 40 yaş civarı genç, orta yaş grubu hastalar. ${ }^{[2]}$

YTO'nun uygun olmadığı hastalar ise 65 yaş üstü ya da medial kompartmanda ileri osteoartriti (Ahlback grade III ve üstü), trikompartmantal osteoartriti, patellofemoral osteoartriti olan, eklem hareket açıklığı $120^{\circ}$ altında, geçirilmiş lateral menisektomi öyküsü olan, obez, $20^{\circ}$ üstü deformitesi olan, $25^{\circ}$ üstü sabit fleksiyon kontraktürü olan, inflamatuvar artrit tanısı olan ve yoğun sigara içen hastalar olarak sayabiliriz. ${ }^{[2]}$ Diğer kompartmanlarda da önemli derecede dejenerasyonu olan bir hastaya YTO veya DFO uygulanması sonrasında başarısızlıkla karşılaşılma ihtimali yüksektir. Dolayısıyla hastayı preoperatif değerlendirmek oldukça önemlidir. Radyolojik, klinik ve hatta gerekirse artroskopik değerlendirme yapılmalıdır. ${ }^{[12]}$

Cerrahi öncesi detaylı ve eksiksiz yapılmış bir fizik muayene ve görüntüleme başarılı sonuç için şarttır. Sadece diz eklemini değil özellikle ilgili ekstremitenin kas-iskelet sistemini de detaylı muayene etmek gerekir. ${ }^{[3]}$ Alt ekstremite deformitelerine ve varsa alt ekstremite uzunluk farkına mutlaka bakmak gerekir. Bilateral basarak önarka tam ekstansiyonda grafiler, dizin $45^{\circ}$ fleksiyonda olduğu Rosenberg grafileri, tüm ekstremitenin uzunluk grafileri gerek deformiteyi saptamak ve anlamak gerekse de eklem boşluk kaybını değerlendirmek için önemlidir. Görüntüleme yöntemleri kullanılarak titiz bir preoperatif plan yapılmalıdır. Deformitenin yeri; proksimal medial tibial açı ve distal lateral femoral açılar önemlidir. Deformitenin yanlış değerlendirilmesi ve yanlış yerden düzeltme (korreksiyon) yapılması eklem çizgisinin değişimine ve dolayısıyla ekleme binen stresin de değişmesine neden olacaktır. ${ }^{[7]}$ Valgus dizilimi olan ve izole lateral kompartman osteoartriti olan bir hastada deformiteyi tibial taraftan düzeltmek, eklem oblikliği yaratabileceği için tartışmalıdır. Bunun yerine distal femoral osteotomi tercih edilmelidir. ${ }^{[12]}$ Shoji ve Insall, valgus korreksiyon osteotomilerinden sonra kalan diz eklem hattının oblikliğinin osteotomiler için önemli bir prognostik faktör olduğunu söylemişler, ayrıca da valgus deformitesi ve lateral kompartman osteoartriti olan hastalarda yaptıkları YTO sonrasında eklem hattı eğikliğinin $15^{\circ}$ 'yi aşması durumunda daha hızlı dejenerasyon olabileceğini söylemişlerdir. ${ }^{[16]}$
Medial tibial platoda aşırı bir kemik kaybı olan hastalarda YTO sonrasında, platolardaki yük dağılımı bozulabilir ve dizde koronal planda instabilite oluşabilir. Lateral tibial subluksasyonun fazla $(>1$ $\mathrm{cm}$ ) olduğu hastalarda YTO sonrasında tibia daha fazla valgusa geleceğinden patellar "maltracking” yani uyumsuzluk artabilir. Dolayısıyla tibial subluksasyonun cerrahi olarak hedeflenmesi gerekir. Yukarıda da bahsedildiği gibi, diz eklem hareket açıklığı kötü olan ve fleksiyon kontraktürü bulunan hastalarda osteotomi sonrasında başarısız bir rehabilitasyon kötü sonuç beklentisini artıracaktır; $20^{\circ}$ üstü korreksiyon gerektiren osteotomilerde ise öncelikle deformitenin ağırlığı nedeniyle prognoz kötü olacaktır. Ayrıca rezidüel kollateral ligament laksitesi oluşabilmekte ve öncesinde de instabilitesi olan bir hastada instabilite daha kötü bir hale gelebilmektedir. İnflamatuar artropatilerde ise hastalığın diğer kompartmanları da etkilemiş olması ve osteotominin inflamasyonu hedeflememesi nedeniyle başarısızlık görülebilmekte, bu gibi durumlarda preoperatif laboratuvar değerlendirmeleri faydalı olabilmektedir. ${ }^{[12]}$

Osteotomilerdeki büyük sıkıntılardan birisi, intraoperatif olarak (ameliyat esnasında) ekstremiteyi bastırmak mümkün olamadığından korreksiyonu net olarak değerlendirmenin pek mümkün olamamasıdır. Bu gibi durumlarda koter kablosu gösterge olmak kaydı ile ve skopi altında ölçüm yapılabilse de bu yöntemin özellikle obezite ve laksitesi bulunan hastalarda güvenilirliği daha da azalmaktadır. ${ }^{[7]}$

Ameliyathanede hazırlık sırasındaki eksikler, yanlışlar, yetersiz takım duyarlılığı yine komplikasyonlara ve başarısızlığa neden olabilmektedir. Örneğin; kalça altı yüksekliğinin konulmaması lateral bölgeyi değerlendirmede zorluk çıkartabilir. Turnike kullanılmaması ya da işlevinin intraoperatif bozulması, cerrahi sırasında zorluk oluşturabilir. Nörovasküler yapıların dikkat dışı kalması ve diz bölgesinin kalemle işaretlenmesi, ana yolakların belirlenmesi gerekir. İntraoperatif vasküler yaralanma ihtimali açısından vasküler cerrahın hazır bulunması da tavsiye edilmektedir. Osteotomi sırasında medial, lateral, anterior ve posterior eğim (slope) açılarının doğru olması için kesme aparatının uygun yerleştirilmesi elzemdir. İstenmeyen bir eğim dizin mekaniğini değiştirebilir ve komplikasyon özellikle postoperatif osteoartrit sürecini hızlandırabilir. ÖÇB yetmezliğinde de instabilite osteoartrite neden olabilir. Kesinin doğal eğime uygun olmasına dikkat edilmelidir. Ĕger intraoperatif olarak eğim bozukluğu fark edilirse daha uygun kesiler ile her yöndeki eğim düzeltilebilir. Fakat bu durumda çok fazla kemik kesmekten kaçınmak gerekir. Farklı görüşler olsa da osteotominin tepesinin, uzak kortekse 10 mm'ye kadar kesilmesi ve 
proksimal fragmanın en azından $15 \mathrm{~mm}$ kalınlıkta bırakılması kırık riskini önlemek açısından yapılmalıdır. Kırık ve hatalı düzeltmeden sakınmak için fluroskopi uygun şekilde ve detaylı değerlendirilerek kullanılmalıdır. YTO sonrasında oluşabilecek patella infera'dan ise sağlam bir internal fiksasyon ve progresif postoperatif mobilizasyon ile korunulabilir. ${ }^{[12]}$

DFO'da ise kısa dönemde enfeksiyon, venöz tromboemboli, aşırı ya da yetersiz düzeltme, intraartiküler kırık, uzak korteksin kırılması, nörovasküler yaralanma, kompartman sendromu veya diz katılığı gibi komplikasyonlar olurken, uzun dönemde gecikmiş kaynama/kaynamama, korreksiyon kaybı, implant başarısızlığı gibi komplikasyonlar görülebilmektedir. Benzer şekilde osteotomi ile eklem arasında yeterli mesafe bırakılmaması eklem içi (intraartiküler) kırıklara neden olabilirken, uzak kortekste yeterli sağlam kemik bırakılmaması uzak korteks kırıklarına neden olabilmektedir. ${ }^{[17]}$

YTO ve DFO'daki komplikasyon oranları literatürde oldukça değişiklik göstermektedir. Vena ve ark.'nın yaptıkları literatür taramasında açık kama YTO için en yüksek komplikasyon oranı $\% 55$, en düşük komplikasyon oranı \%1,9 olarak saptanmış. Kapalı kama YTO'da ise en yüksek \%34, en düşük $\% 10$, DFO için ise en yüksek \%70, en düşük \%19 oranları saptanmış. ${ }^{[7]}$ Fakat DFO'da özellikle yüksek komplikasyon oranı veren çalışmalar eski yıllara ait olduğundan fiksasyon metotlarındaki değişimi göze alarak bu oranları yorumlamak daha uygun olacaktır. Duivenvoorden ve ark.'nın yaptıkları altı yıllık takip süresi olan randomize kontrollü çalışmada medial açık kama osteotomilerinde daha çok komplikasyon görülürken, lateral kapalı kama osteotomilerinin artroplastiye daha erken gittiği belirtilmiştir. ${ }^{[18]}$ Yine bu çalışmada açık kama tekniğinde en sık komplikasyon ya da sorun implant çıkarımı ve iliak kanattan alınan greft nedeniyle donör bölge morbiditesi iken lateral kapalı kama tekniğinde ise implant çıkarımı ve artroplastiye dönüşüm olarak belirtilmiştir. ${ }^{18]}$

Wylie ve ark.'nın yaptıkları bir sistematik derlemede 372 distal femoral osteotomi değerlendirilmiş.. ${ }^{[1]}$ Ortalama takip süresi $45-180$ ay olarak belirtilmiş, \%3,2 kaynamama, \%3,8 gecikmiş kaynama ve total olarak \%9'luk bir komplikasyon oranı gösterilmiş. Komplikasyonlar; kırık, implant malpozisyonu, korreksiyon kaybı, enfeksiyon, hematom, tromboz/pulmoner emboli, implant başarısızlığı, artrofibrozis olarak dağılmıştır. Medial kapalı kama ve lateral açık kama tekniklerinin benzer sonuçlar verdiği belirtilmiş. Medial kapalı kamada artroplastiye gidişin daha fazla olduğu fakat bu durumun, bu gruptaki hastaların takip sürelerinin daha uzun olması ile ilişkilendirilebileceği belirtilmiştir. ${ }^{1]}$
2014 yılında yapılan bir sistematik derlemede medial kompartman osteoartritinde YTO ağrıyı azaltan ve fonksiyonu iyileştiren etkili bir teknik olmasına rağmen, farklı teknikler arasında herhangi belirgin ve anlamlı bir fark saptanmamıştır. Ayrıca YTO'nun unikondiler artroplasti veya cerrahi dışı tedaviden daha efektif olduğunu gösteren belirgin ve net bir kanıt bulunmamaktadır. ${ }^{[19]}$ Uzun dönemde iyi sonuç ve az komplikasyon; doğru hasta seçimi, uygun cerrahi, fiksasyon tekniği ve optimal bir postoperatif yönetim ile doğrudan ilişkilidir. ${ }^{[2]}$

Kullanılan teknik ve metoda göre komplikasyon oranları farklılık gösterse de özellikle popliteal bölgedeki nörovasküler yapıların hasarlanması osteotomi prosedürünün en ciddi komplikasyonunu oluşturmakla beraber görülme oranı daha düşüktür. Sıklıkla aşırı veya yetersiz düzeltme, implant başarısızlığı ile karşılaşılmaktadır. Varus diz deformitelerinin tedavisi için şu aralar daha popüler bir yöntem olan medial açık kama YTO'da daha hassas bir düzeltme sağlar ve kapalı kamada görülen bazı komplikasyonlar daha az oranda görülürken özellikle patella infera ve tibial eğim modifikasyonları bu teknikte daha olası görülebilmektedir. Bunun yanı sıra medial açık kamada, kas diseksiyonundan kaçınma, peroneal sinir yaralanma oranlarında azalma ve kemik stoğunun korunması gibi avantajlar da bulunmaktadır. Ancak literatürde açık ve kapalı kama teknikleri ile ilgili farklı sonuçlar bildirilmiştir. ${ }^{[7]}$

Açık kama osteotomisinde, fibula osteotomisine gerek duyulmadığından fibula kaynaması ve peroneal sinir ile ilgili problemlerden uzak kalınır. Fakat tibia kaynaması ile ilgili komplikasyonlar görülebilmektedir. ${ }^{[20]}$ Kapalı kama osteotomisinde ise kaynama daha az bir problem yaratırken, peroneal sinir hasarı daha olasıdır. Song ve ark. ${ }^{[21]}$ yaptıkları çalışmada kapalı ve açık kama osteotomileri, genel ve majör komplikasyonlar açısından karşılaştırmış ve her iki grup arasında anlamlı bir fark bulamamışlardır. Bu çalışmada obezitenin, YTO sonrasında majör komplikasyonlar açısından bağımsız bir risk faktörü olduğu belirtilmiştir. Coventry ve ark. da ideal vücut ağırlığının \%30 ve üstündeki hastalarda başarısızlık açısından artmış bir risk olduğunu belirtmişlerdir. ${ }^{[22]}$

Sun ve ark. yaptıkları metaanalizde medial diz osteoartritinde kapalı kamada karşı korteks kırığının anlamIı olarak yüksek insidansta görüldüğünü fakat implant çıkarımının daha az olduğunu söylemişlerdir. Yüzeyel enfeksiyon, derin ven trombozu (DVT), revizyon ve peroneal sinir hasarı açısından açık ve kapalı kama arasında anlamlı fark bulamamışlardır. ${ }^{[23]}$

Brouwer ve ark. ${ }^{[24]}$ yaptıkları bir çalışmada YTO sonrasında patellar yükseklik (patellar height) ve tibial plato 
eğimini (slope) karşılaştırmışlar. Açık kamada, kapalı kamaya göre patellar yüksekliğin anlamlı olarak daha fazla düştüğünü belirtmişler. Tibial plato eğiminin ise açık kamada artarken, kapalı kama sonrasında anlamlı olarak azaldığını belirtmişlerdir.[24]

El-Azab ve ark.'nın 100 vakalık valgus YTO serisinin radyolojik değerlendirilmesini yaptıkları çalışmada açık kama $(n=50)$ ve kapalı kama $(n=50)$ teknikleri karşılaştırılmış. Patella infera insidansının açık kama sonrası arttığı, patella supera insidansının ise kapalı kama sonrası arttığı saptanmıştır. ${ }^{[25]}$

Zhan ve ark.'nın yaptıkları bir metaanalizde açık ve kapalı kama YTO karşılaştııılmış. Diz ağrı skorları, yürüme mesafesi gibi durumlarda arada anlamlı fark saptanmamış. Her iki grup arasında sağkalım ve komplikasyon açısından da anlamlı fark bulunamamış (p>0,05). Açık kama YTO'da anlamlı olarak daha fazla bir posterior tibial eğim açısı saptanmış. Kapalı kama YTO tibial plato eğimini düşürürken, açık kamanın posterior eğimi arttırdığı dile getirilmiş. Dolayısıyla hasta bazlı olarak değerlendirme ve tercih gerektiği belirtilmiş. ${ }^{[26]}$ Fakat her iki tekniğin genel olarak birbirlerine belirgin bir üstünlüğü saptanmamış.

Ducat ve ark. yaptıkları prospektif çok merkezli çalışmada açık kama osteotomisinde posterior tibial eğimin arttığı, kapalı kamada azaldığını söylemişlerdir. ${ }^{[27]}$ Bunun nedeni olarak kapalı kama osteotomi tekniğinde, osteotomi boşluğunun anteriora doğru kapanması; açık kama tekniğinde ise açılmanın anteriorda daha fazla olduğu söylenebilir. Bunun önüne geçebilmek için özellikle posterior yumuşak doku gevşetilmesinin yerinde yapılması ve tibia arka korteksinin osteotomisinin tam olarak yapılması önerilmektedir. Ayrıca açık kama osteotomisinde plağın çok fazla öne yerleştirilmemesi ve posteriorun yeteri kadar açıldığına dikkat edilmesi gerekmektedir. ${ }^{[7]}$

Woodacre ve ark. ${ }^{[28]}$ medial kompartman osteoartriti için yapılan açık kama YTO hastalarını taramışlar. Toplam 115 hasta çalışmaya dâhil edilmiş. Ortalama takip 8,4 yıl (2-16 yıl). Cerrahi sırasında ortalama yaş 47 yıl (32-62). Yetmiş beş hastanın VKI'sine bakılabilmiş. Ortalama VKi $29,1 \mathrm{~kg} / \mathrm{m}^{2}(20,3-40,2)$. Fiksasyonda üç farklı implant kullanılmış; \%72'sinde $(n=83)$ Tomofix, \%21'inde $(n=24)$ Puddu plağı, $\% 7$ 'sinde $(n=8)$ Orthofix. Kırk hastada herhangi bir kemik grefti kullanılmamış. Kırk hastada beta trikalsiyum fosfat (Chronos) ve 35 hastada otogreft (\%16'sı distal femur, \%14'ü iliak kanattan) kullanılmış. İmplantlar arasında anlamlı bir fark saptanmamış. Beş yıllık sağkalımı olan hastalarda VKi $28,6 \mathrm{~kg} / \mathrm{m}^{2}$ (sd 4,26), artroplastiye gidenlerde VKi $29,3 \mathrm{~kg} / \mathrm{m}^{2}$ (sd 2,96) olarak saptanmış. Fakat bu fark anlamlı olarak bulunmamış. Toplamda 29 hastada total olarak 36 komplikasyon görülmüş; Total komplikasyon oranı \%31. Diğer olarak sınıflandırılan komplikasyonlar ise bir adet kırılmış vida, bir hatalı dizilim, bir yara bölgesinde hiperestezisi, bir iliak kanatta inatçı ağrı, bir radyolojik kaynamaya rağmen osteotomi hattında inatçı ağrı olarak belirtilmiş (Tablo 1). ${ }^{[28]}$

Aynı çalışmada implant türü ile kaynamama arasında anlamlı ilişki saptanmamış. İstatistiksel olarak

Tablo 1. Woodacre ve ark.'nın ${ }^{[28]}$ yaptıkları çalışma sonuçları

\begin{tabular}{|c|c|c|c|c|}
\hline İmplant & Hepsi & Tomofix & Puddu & Orthofix \\
\hline Revizyon gerektiren kaynamama & $\% 4,3(n=5)$ & $\% 3,6(n=3)$ & $\% 8,3(n=2)$ & $\% 0$ \\
\hline Kırık & $\% 0$ & $\% 0$ & $\% 0$ & $\% 0$ \\
\hline İmplant çıkarımı gerektiren plak rahatsızlığı & $\% 7(n=8)$ & $\% 7,2(n=6)$ & $\% 8,3(n=2)$ & \\
\hline İmplant başarısızlığı & $\% 0$ & $\% 0$ & $\% 0$ & $\% 0$ \\
\hline Minör yara yeri enfeksiyonu & $\% 9,6(n=11)$ & $\% 8,4(n=7)$ & $\% 8,3(n=2)$ & $\% 25(n=2)$ \\
\hline Majör yara yeri enfeksiyonu & $\% 3,5(n=4)$ & $\% 2,4(n=2)$ & $\% 0$ & $\% 25(n=2)$ \\
\hline DVT & $\% 0$ & $\% 0$ & $\% 0$ & $\% 0$ \\
\hline Vasküler yaralanma & $\% 1,7(n=2)$ & $\% 2,4(n=2)$ & $\% 0$ & $\% 0$ \\
\hline Kompartman sendromu & $\% 0,9(n=1)$ & $\% 1,2(n=1)$ & $\% 0$ & $\% 0$ \\
\hline Diğer & $\% 4,3(n=5)$ & $\% 2,4(n=2)$ & $\% 12,5(n=3)$ & $\% 0$ \\
\hline
\end{tabular}


anlamlı olmasa da kemik grefti konulmayan popülasyonda \%5, otogreft konulanlarda \%13, sentetik greft konulanlarda ise $\% 0$ kaynamama görülmüş. Kaynamama olan popülasyonun VKi ortalama 28,9 $\mathrm{kg} / \mathrm{m}^{2}$ iken harici popülasyonda $28,4 \mathrm{~kg} / \mathrm{m}^{2}$ olarak saptanmış. Fakat anlamlı bir fark tespit edilmemiş. VKI'sine bakılan 75 hasta değerlendirildiğinde ise komplikasyonlar ile arasında anlamlı bir ilişki saptanmamış. Komplikasyon olanlarda VKi ortalama 29,2 $\mathrm{kg} / \mathrm{m}^{2}$ iken komplikasyon olmayanlarda ortalama $29,1 \mathrm{~kg} / \mathrm{m}^{2}$ olarak bulunmuş. Aynı zamanda cerrahi sırasındaki yaş ile genel komplikasyon oranı arasında da anlamlı fark bulunamamış. ${ }^{28]}$

Van den Bekerom ve ark. ${ }^{[29]}$ Puddu plağı ile yaptıkları ve sentetik kansellöz kemik kullandıkları medial açık kama YTO'larda komplikasyon oranını \%55 olarak belirtmişlerdir. AO/ASIF L-plak ile yapılan kapalı kama karşılaştırmasında Puddu plağı kullanılan açık kamada anlamlı fark saptamışlar. Hoell ve ark. ${ }^{[30]}$ ise Puddu plağı ile \%13,7 komplikasyon oranı bildirmişlerdir. Nelissen ve ark. ${ }^{[31]} 49$ medial açık kama YTO vakasında Puddu plağı ile \%45 komplikasyon oranı belirtmiş ve korreksiyonun 10 mm'yi aştığı durumlarda komplikasyon oranının arttığını söylemişlerdir. Spahn ${ }^{[32]} 55$ hastada Puddu plağı, 30 hastada ise C-plak kullanmış ve sonucunda Puddu plağı kullanılan grupta anlamIı şekilde fazla komplikasyon görüldüğünü (sırasıyla $\% 43,6$ ve $\% 16,7)$ saptamıştır.

Valkering ve ark. ${ }^{[3]}$ Tomofix plağı ile medial açık kama YTO komplikasyonlarına bakmışlar. Dört vakada yüzeyel enfeksiyon, bir vakada 12 ay sonunda implant çıkarımı yapılırken bir vidanın kırılmış olduğu görülmüş. Kaynamama saptanmamış, vida kırılan vaka dışında herhangi bir implant başarısızlığı belirtilmemiş. Niemeyer ve ark. ${ }^{[34]}$ Tomofix plağı kullanarak açık kama osteotomide majör komplikasyon oranını $\% 8,6$ olarak saptamışlardır. Hastaların büyük çoğunluğunda $(\% 40,6)$ implanta bağlı rahatsızlık görülmüş. Bu fiksasyon cihazının en büyük dezavantajlarından biri olarak bu durumu ortaya atmışlardır. Chae ve ark. ${ }^{[35]}$ T-plak ve otolog trikortikal iliak kemik grefti kullandıkları medial açık kama çalışmalarında 138 vakada \%18,8 komplikasyon oranı bildirmişlerdir.

Ren ve ark.'nın yaptıkları metaanalizde açık kama YTO'da greft kullanımını araştırmışlar. Çalışma sonucunda korreksiyon kaybı ve komplikasyonlar açısından otogreft ve allogreft kullanılan grup ile herhangi bir greft kullanılmayan grup arasında anlamlı fark bulamamışlar. Greft kullanılmayan grupta daha iyi diz skorları elde etmişler. İkinci operasyon gerekliliği, lateral korteks kırığı, komplikasyonlar ve klinik fonksiyonlar açısından oto ve allogreft arasında anlamlı fark saptanmamış. Allogreft grubunda cerrahi süre otogrefte göre istatistiksel olarak daha düşük bulunmuş. Sonuç olarak ise açık kama YTO'da greft kullanımının komplikasyonları etkilemediğini söylemişlerdir. ${ }^{[36]}$

Kuremsky ve ark. benzer teknik ve sistemi kullanarak allogreft ve otogreft karşılaştırması yapmışlar. Allogreft grubunda altı kat daha fazla başarısızlık oranı saptamışlar. Ayrıca $11 \mathrm{~mm}$ açılmayı komplikasyon oranını artıran sınır değer olarak belirlemişlerdir. ${ }^{[37]}$

Gouin ve ark. ise otogreft ve kalsiyum fosfat seramik "spacer" yani ara destekleyici kullanılan hastalar arasında komplikasyonlar açısından herhangi bir anlamlı fark saptamamışlardır. ${ }^{[38]}$

Jacobi ve ark. ${ }^{[39]}$ Tomofix plağı ile 14 hastaya lateral DFO prosedürü uygulamış. On iki hastada (\%86) iliotibial band irritasyonu raporlamışlar. Stahelin, ve ark. ${ }^{[40]} 21$ kapalı kama DFO vakasına biçimlendirilebilir semitubuler plak kullanmış ve beş komplikasyon bildirmişlerdir. Birinde korreksiyon kaybı nedeniyle revizyon gerekmiş. Ikisinde subkutan hematom, birinde popliteal ven trombozu, birinde ise yüzeyel yara enfeksiyonu bildirmişlerdir.

Miller ve ark.'nın 46 medial açık kama YTO vakasında, \%36,9 oranında komplikasyon bildirilmiştir. Yedi vakada $(\% 15,2)$ korreksiyon kaybı, iki $(\% 4,3)$ vakada intraoperatif lateral korteks kırığı, iki $(\% 4,3)$ hastada postoperatif lateral korteks kırığı, iki $(\% 4,3)$ hastada derin ven trombozu, iki hastada gecikmiş kaynama ve iki hastada implanta bağlı semptomlar görülmüş. Yedi korreksiyon kaybı vakasının altısında 1. jenerasyon fiksasyon cihazı (Puddu plağının erken versiyonu) kullanıldığı belirtilmiş. Fiksasyon tipi ile korreksiyon kaybı arasında anlamlı bir ilişki gösterilmiş. ${ }^{41]}$

Brouwer ve ark. tarafindan 47 kapalı kama ve 45 açık kama vakası değerlendirmiş. Kapalı kamada "staple” ile fiksasyon, açık kamada ise Puddu plağı kullanmışlar. Ağrı, diz skorları açısından gruplar arasında anlamlı fark saptanmamışken açık kama grubunda daha fazla komplikasyon görülmüş. Kapalı kama ile tedavi edilen grupta 11 vakada (\%23) implant çıkarımı gereksinimi olmuşken, açık kama ile tedavi edilen grupta 27 vakada (\%60) implant çıkarımı gereksinimi olmuş. ${ }^{[42]}$

Pilone ve ark.'nın ${ }^{[43]}$ yayımladıkları lateral açık kama DFO yazısında komplikasyonları intraoperatif ve postoperatif olarak ayırmışlar. En sık görülen intraoperatif komplikasyonları, intraartiküler kırık ve medial menteşe noktasının kırı̆̆ı olarak saptamışlar. İnkomplet bir osteotominin yapılması ya da kılavuz telinin ekleme çok yakın yerleştirilmesi eklem içi kırıklara neden olabilmektedir. Postoperatif olarak korreksiyon kaybı, kaynamama, DVT, kompartman sendromu ve enfeksiyon gibi komplikasyonlar bildirmişlerdir. Kaynamama oranını yaklaşık \%5 olarak saptamışlardır. Yetersiz 
fiksasyonun veya progresif bir rehabilitasyonun; implant başarısızlığı, osteotomi hattının kollapsı ve korreksiyon kaybı ile sonuçlanabileceği söylenmiş. DFO için herhangi bir fiksasyon cihazının diğerlerine üstünlügüü net olarak kanıtlanamamıştır. Fakat literatürde özellikle iliotibial band irritasyonu nedeniyle $\% 86$ gibi oranlara varabilen implant çıkarımı gereksinimi gösterilmiştir. Aynı şekilde osteotomi boşluğunda greft kullanımı veya hangi greftin kullanılacağı konusunda optimal bir seçim standardı belirtilmemiştir. ${ }^{[43]}$

Han ve ark.'nın ${ }^{[4]}$ yaptıkları çok merkezli bir çalışmada kilitli plak ile yapılan medial açık kama YTO hastaları incelenmiş. Çalışmaya en az iki yıl takibi olan 209 vaka dahil edilmiş. Ortalama yaş 56,4 ve ortalama komplikasyon oranı \%29,7 olarak saptanmış. Minör komplikasyon olarak nondeplase lateral menteşe bölge kırığı (\%12), implant irritasyonu $(\% 1,4)$, deplase lateral menteşe bölge kırığı $(\% 2,4)$, gecikmiş yara iyileşmesi $(\% 1,9)$, nondeplase lateral tibia plato kırı̆̆ı (\%1) ve yüzeyel yara enfeksiyonu (\%1) görülmüş. Majör komplikasyon olarak ise implant çıkarımına neden olan irritasyon $(\% 4,8)$, derin yara enfeksiyonu $(\% 1,9)$, korreksiyon kaybıyla beraber implant başarısızlığı (\%1), kaynamama $(\% 0,5)$, artroplastiye erken dönüş $(\% 0,5)$ saptanmış. Komplikasyonların büyük çoğunluğunun intraoperatif $(\% 30,6)$ ve postoperatif ilk üç ay $(\% 40,3)$ içerisinde meydana geldiği belirtilmiş.

Osteotomi işleminde eksternal fiksasyon ile ilgili yayınlar da bulunmaktadır. Eksternal fiksasyon tekniğinde literatürde özellikle pin ile ilişkili enfeksiyonlar açısından yüksek oranlar bildirilmiştir. ${ }^{[7]}$ Üç yüz sekiz vakalık bir seride $\% 51$ oranında pin dibi enfeksiyonu ve bir vakada septik artrit görülmüştür. ${ }^{[45]}$ Adili ve ark.'nın yaptıkları çalışmada 15 vakalık ilizarov grubunda 10 vakada enfeksiyon bildirilmiş fakat tüm enfeksiyon vakalarının oral antibiyotik ve/veya enfekte pinin çıkarılması ile düzeldiği söylenmiştir. ${ }^{[46]}$ Aynı seride dört vakada ayak bileğinde hareket kısıtlılığı ve dört vakada DVT görülmüş. Eksternal fiksatör tekniğinde enfeksiyon oranı diğer tekniklere göre daha fazla görülse de (\%37-50) bunların çoğu çivi (pin) ile iliş̧kili enfeksiyonlar şeklindedir ve uygun antibiyoterapi ile sorun çözülebilmektedir. ${ }^{[7]}$

Zhim ve ark.'nın 12 taze donmuş kadavra diz üzerine yaptıkları çalışmada internal fiksasyonun, eksternal fiksasyona göre daha dayanıklı olduğu ve korreksiyon kaybının daha az olduğunu göstermiştir. ${ }^{[47]}$

Haviv ve ark.'nın ${ }^{[48]}$ valgus artritik dizlerde düzeltici osteotomi ile ilgili literatür taramasında proksimal tibia osteotomisinde erken serilerde geniş düzeltme yapılan hastalarda postoperatif instabilite, medial tilt, eklem oblikliği görülebildiği belirtilmiştir. Romatoid hastalarda ise sonucun daha kötü olduğu söylenmiştir. DFO'da eklem katılığı, kaynamama ve implant başarısızlığı gibi komplikasyonların meydana geldiği bildirilmiş. Geçmişte yapılan çalışmalarda özellikle "staple" kullanılan vakalarda kaynamama, korreksiyon kaybının olabildiği görülmüş ve günümüzde bu fiksasyonun yeterli olmadığı ortaya çıkmıştır. ${ }^{[48]}$

Hernigou ve ark. kilitli plak kullanarak eş zamanlı ve basamaklı bilateral açık kama YTO vakalarını karşılaştırmışlar. Toplamda 90 hastaya aynı plak-vida tespiti uygulanmış. Otuz beş hastaya eş zamanlı bilateral YTO yapılırken, 55 hastaya basamaklı, farklı seansta bilateral YTO yapılmış. Basamaklı cerrahi yapılan hastalarda anestezi süresi ve ameliyathanede geçirilen süre \%35 daha fazla saptanmış. Eş zamanlı yapılan vakalarda kan kaybı daha fazla saptanmış. Eş zamanlı vakalarda tromboflebit sıklığı ve antikoagülan kullanım uzunluğu, basamaklı cerrahilerin toplamından daha düşük saptanmış. Eş zamanlı yapılan hastalarda koltuk değneği kullanımı basamaklı cerrahiye göre daha uzun belirlenmiş. Eş zamanlı yapılan cerrahilerde gecikmiş kaynama, basamaklı cerrahiye göre daha düşük saptanmış. Basamaklı cerrahi yapılan hastalarda, eş zamanlı olanlara göre iki kat fazla komplikasyon riski olduğu söylenmiş. Fakat eş zamanlı YTO uygulanan hastalarda kan transfüzyon gereksinim riski daha fazla olarak raporlanmıştır (Tablo 2). ${ }^{[49]}$

Tablo 2. Hernigou ve ark.'nın çalışma sonuçları ${ }^{[49]}$

\begin{tabular}{|c|c|c|c|}
\hline & Eş zamanlı bilateral YTO ( $n=35)$ (70 diz) & Basamaklı bilateral YTO ( $\mathrm{n}=55)$ (110 diz) & $\mathrm{p}$ değeri \\
\hline Yara enfeksiyonu & 0 & $3 \operatorname{diz}$ (3 hasta) & 0,05 \\
\hline Gecikmiş kaynama ve kaynamama & 0 & $\begin{array}{l}4 \text { diz (4 hasta) } \\
3 \text { gecikmiş kaynama; } 1 \text { kaynamama }\end{array}$ & 0,07 \\
\hline Lateral plato kırığı & $1 \mathrm{diz}$ (1 hasta) & $2 \operatorname{diz}$ (2 hasta) & 0,36 \\
\hline İmplant çıkarımı & 0 & $2 \operatorname{diz}$ (2 hasta) & 0,42 \\
\hline Artroplastiye revizyon & 0 & $2 \operatorname{diz}(2$ hasta $)$ & 0,24 \\
\hline
\end{tabular}


Lash ve ark.'nın yaptıkları derlemede açık kama osteotomi yapılan hastalar incelenmiş. Ortalama yaş 50 (27-69), ortalama takip 42 ay (3-312 ay). Toplamda 3033 vakanın 2926'sına medial açık kama tibial osteotomi, 55'ine lateral açık kama tibial osteotomi ve 52 'sine lateral açık kama DFO yapılmış. Toplamda 2950 (\%97) vakaya fiksasyon yapılmış. İki bin sekiz yüz yetmiş yedi medial tibial osteotominin 2148'i (\%75) kilitli olmayan plaklar veya kilitli olmayan vidalar ve spesifik YTO plakları ile fikse edilmiş; $681^{\prime} i(\% 24)$ ise kilitli vida-plak ile fikse edilmiş. Kırk sekiz vakada eksternal fiksatör kullanılmış. Yirmi bir lateral tibial açık kama osteotomi vakasında kilitli olmayan plaklar kullanılmış. Elli iki lateral femoral osteotomi vakasının 14'ünde kilitli plak, 38'inde ise kilitli olmayan plaklar kullanılmış. Aradaki boşluğu doldurmak için allogreft $(\% 25,9)$, otogreft $(\% 29,5)$, trikalsiyum fosfat $(\% 12,6)$, kalsiyum fosfat $(\% 7,2)$, hidroksiapatit/trikalsiyum fosfat $(\% 3,4)$, "bioglass" $(\% 1,7)$, kombine materyaller vb. kullanılmış. Vakaların \%17,3'ünde ise herhangi bir materyal kullanılmamış. Gecikmiş kaynama/kaynamama oranları otogreft için \%2,6, allogreft için \%4,6 ve sentetik kemik materyalleri için $\% 4,5$ olarak saptanmış. Otogreft kullanılan vakalarda kaynamama ve gecikmiş kaynama oranı allogrefte göre anlamlı olarak düşük saptanmış. Otogreft ve allogreftin ise sentetik kemik materyallerine göre anlamlı olarak daha düşük kaynamama/gecikmiş kaynama oranı olduğu saptanmış. Kilitli olmayan plaklarda gecikmiş kaynama/kaynamama oranı \%3,7 ve zamanla ortalama korreksiyon kaybı $0,5^{\circ}$ olarak; kilitli plaklarda ise \%2,6 ve korreksiyon kaybı $2,3^{\circ}$ olarak raporlanmış. Kaynama oranları açısından kilitli ve kilitli olmayan plaklar arasında fark bulunmamış. Sonuç olarak ise gecikmiş kaynama/ kaynamama oranları otogreft kullanılan vakalarda en düşük olarak saptanmış. Kullanılan plağın kaynamayı ve korreksiyon kaybını etkilemediği belirtilmiştir. ${ }^{[50]}$

Tüm bu komplikasyonların yanı sıra osteotomi prosedürlerinin akut interstisyel pankreatit gibi çok nadir görülen gastrointestinal ve diğer komplikasyonları da bulunmaktadır. ${ }^{[51]}$ Ayrıca Türkmen ve ark., 55 yaşında bir kadın hastada proksimal tibial osteotomi sonrasında pnömotik turnike kullanımına bağlı akut rabdomiyoliz olgusu saptamışlardır. ${ }^{[52]}$

\section{Deformite Rekürrensi (Tekrarı) - Yetersiz Düzeltme}

Rekürrens, ağrıya neden olabilen postoperatif majör bir komplikasyondur. Uzun dönem çalışmalarda klinik başarının zamanla kötüleştiği gösterilmiştir. ${ }^{[12]}$ Varus rekürrensi hastaların \%30'una kadar görülebilmektedir. Nedenleri ise sıklıkla cerrahi sırasında yetersiz düzeltme, fiksasyon eksikliği ve eklem güçlerinin dengesinin iyi sağlanamaması olarak sıralanabilir. ${ }^{[20]}$ Deformitenin aşırı düzeltilmesi yani "overcorrection" ile bu komplikasyondan korunulabilir. Coventry, en azından $8^{\circ}$ valgus aşırı düzeltmesi yapılmazsa başarısızlık riskinin artabileceğini söylemiştir. ${ }^{[22]}$ Preoperatif plan çok dikkatli yapılmalı ve düzeltme miktarı hesaplanmalıdır. İntraoperatif dikkatli bir düzeltme yapılmalıdır. Bilinmelidir ki yukarıda da bahsedildiği gibi intraoperatif tam anlamıyla bilgisayar destekli ölçüm dışında güvenilir bir ölçüm yöntemi henüz yoktur. Dolayısı ile dizilim postoperatif grafiler ile mutlaka değerlendirilmelidir. Bu problemin çözümünde ise genel olarak revizyon osteotomiler, artroplasti ve ortezler kullanılabilmektedir. ${ }^{[12]}$

Biyomekanik olarak mekanik aks diz merkezinden valgusa doğru kaydığında medial kompartmanın taşıdığı yük azalmaktadır. ${ }^{[33]} \mathrm{Bu}$ nedenle birçok yazar $2^{\circ}$ ile $6^{\circ}$ mekanik valgus arasında bir dizilim önermektedir. Yukarıda da bahsedildiği gibi Coventry ve ark. $8^{\circ}$ bir valgus önermektedir. ${ }^{[22]}$ Hernigou ve ark. ise en iyi sonuçları $3^{\circ}-6^{\circ}$ bir valgusta gördüklerini ve $6^{\circ}$ üzerinde bozulmalar olduğunu belirtmiştir. ${ }^{[54]}$

Aşırı düzeltme ise sık görülmese de patellar subluksasyon ve patella infera gibi sorunlara yol açabilmektedir. ${ }^{[20]}$

ideal mekanik dizilim ve düzeltme konusunda çok fazla tartışma bulunmakla birlikte birçok yazar uzun vadede daha iyi sonuç verebilen en az $5^{\circ}$ lik bir aşırı düzeltmeyi önermektedir. YTO uygulanırken yetersiz düzeltme yapılması daha yüksek revizyon ve artroplastiye dönüş ile ilişkili olarak saptanmıştır. ${ }^{[5]}$

Günümüzde düzeltme miktarını daha iyi ayarlayabilmek ve oluşabilecek hataları en aza indirmek için bilgisayar destekli kılavuzların kullanıldığı çalışmalar da bulunmaktadır. ${ }^{[55]}$

\section{Kırıklar}

Osteotomi aslında kontrollü bir kırık oluşturma işlemidir. YTO'da uzak kortekste menteşe şeklinde bir alan bırakılarak kama şekli oluşturulur. Karşı kortekse belirli bir mesafede osteotominin durması önerilir. Bu mesafe farklı yazarlar tarafindan farklı şekilde önerilmekte$\operatorname{dir}(5-10 \mathrm{~mm})$. Kapalı kama osteotomisinde düzeltme (korreksiyon) sırasında menteşe bölgesinde plastik deformasyon ve mikrokırıklar görülür. Kırığın eklem içine ve karşı kortekse uzanmamasına dikkat edilmelidir. ${ }^{\left[{ }^{5]}\right.}$

Kortikal menteşe bölge kırıkları korreksiyon kaybı, implant başarısızlığı, yanlış kaynama ve kaynamama gibi sorunlara neden olabilmektedir. ${ }^{[7]}$ Lateral korteks kırıkları kısıtlı plastisite nedeniyle $8^{\circ}$ üzeri düzeltmelerde \%90'lara varan oranda görülebilmektedir. ${ }^{[35]}$ Fakat genel olarak kırık insidansı açık kama için \%25'lere, kapalı kama için ise \%10-20'lere çıkabilmektedir. DFO için ise fazla veri bulunmamaktadır. ${ }^{[7]}$ 
Yeterli bir düzeltme sağlama ve bunu devam ettirmek için kapalı kama osteotomide medial kortikal menteşe bölgesinin sağlam kalması önemlidir. Medial kortekste oluşan bir kırık osteotomi fragmanlarının deplasmanına, korreksiyonun kaybına ve rekürrense neden olabilmektedir. Özellikle fazla düzeltme gereken vakalarda bu komplikasyondan kaçınmak oldukça zor olmaktadır. Bir kadavra çalışmasında karşı korteksin kırılması öncesinde kamanın maksimum açıları kapalı kama YTO'da 6,70, açık kama YTO'da ise $6,5^{\circ}$ olarak saptanmıştır. [56]

Van Raaij ve ark.'nın yaptıkları çalışmada 44 kapalı kama ve 43 açık kama YTO vakasında kapalı kamada 36 (\%82) hastada, açık kamada 15 hastada karşı kortekste kırık oluştuğu bildirilmiştir. ${ }^{[57]}$ Yazarlar bu komplikasyonun tamamen önlenebilir olmadığını, özellikle fazla korreksiyon gereken durumlarda karşı kortekste kırı̆̆ın oluşabileceğini söylemiştir. Kapalı kamada sık görülme nedeninin ise kama şeklinde kemiğin özellikle osteotomi apeksinde yeterince iyi çıkarılamaması olduğunu belirtmektedir. Yüksek oranda görülen karşı korteks kırığına rağmen, van Raaij ve ark.'nın çalışmasında varus açılanmasında bir rekürrens veya anlamlı bir yanlış kaynama saptanmamıştır. Fakat medial açık kamadaki lateral korteks kırı̆gııın instabilite yarattığını söylemiştir. Yazarlar, açık ve kapalı kama karşılaştırması yaptığı bu çalışmasında karşı korteks kırığının lateral kapalı kama tekniğinde daha muhtemel olduğunu fakat korreksiyonun açık kamaya göre daha iyi devam ettirildiğini söylemişlerdir. ${ }^{[57]}$

Spahn, 85 vakalık serisinde 10 kortikal kırık saptamış ve $11^{\circ}$ 'den fazla düzeltmelerde bu durumun önlenebilir olmadığını belirtmiştir. ${ }^{[32]}$

Kortikal kırık insidansı hem kapalı hem açık YTO ve çeşitli fiksasyon metotlarına göre \%9-80 arasında görülebilmektedir. Bae ve ark.'nın ${ }^{[58]}$ yaptıkları bir çalışmada bilgisayar yardımlı kapalı kama YTO'da kortikal kırık insidansını araştırmışlardır. Yüz doksan hasta ve 200 dizlik seride hasta popülasyonunun \%28'inde (56 vaka) nondeplase kortikal kırık, \%6,5'inde (13 vaka) ise deplase kortikal kırık saptamışlardır. Herhangi bir plato kırığı görülmemiştir. Özellikle genç hastalarda ve fazla korreksiyon gereken durumlarda anlamlı şekilde deplase kırık görülme oranının fazla olduğunu belirtmişlerdir. ${ }^{[58]}$

Plato kırıkları da intraoperatif olarak sık görülebilen komplikasyonlardandır. Düzeltme sırasında yeterli derinlikte osteotomi yapılamamasından kaynaklanabilmektedir. ${ }^{[3]}$ Herhangi bir intraartiküler kırık durumunda intraoperatif olarak fluroskopi ile kırık, eklem yüzeyi ve instabilite mutlaka değerlendirilmeli, gerektiğinde redüksiyon ve fiksasyon uygulanmalıdır.
Takeuchi ve ark. medial açık kama YTO prosedüründe oluşan lateral kortikal kırıkları araştırmış ve sınıflamışlardır. ${ }^{[59]} 104$ dizden (93 hasta) oluşan serilerinde \%25 oranında lateral korteks kırığı saptamışlardır. 19 hastada kırık osteotomi uzantısı şeklinde ve tibiofibular eklem civarında görülmüş (Tip I). Beş hastada kırık tibiofibular eklemin distal kısmına uzanmış (Tip II). İki hastada lateral plato kırığı görülmüş (Tip III). Tibiofibular eklemin distaline uzanan kırığı bulunan beş hastanın ikisinde $3^{\circ}-7^{\circ}$ korreksiyon kaybıyla beraber gecikmiş kaynama bildirilmiş. On dokuz hastada ise ek başka bir komplikasyon görülmemiş. ${ }^{[59]}$

Stoffel ve ark. yaptıkları açık kama YTO biyomekanik çalışmasında lateral korteksin sağlam kalmasının YTO sonrası stabiliteyi büyük ölçüde belirlediğini söylemiş̧tir. Ayrıca lateral korteks kırı̆̆ında Tomofix plağının hem kompresyon hem de torsiyonel açıdan Puddu plağına daha üstün olduğunu belirtmiştir. ${ }^{[60]}$

Lateral menteşe ve intraartiküler kırık komplikasyonları açısından diğer cerrahilerde olduğu gibi bir öğrenme eğrisi bulunmaktadır. Ĕger bir lateral korteks kırı̆ı saptandıysa, postoperatif rehabilitasyon dikkatli yapılmalı ve gerekirse fiksasyonu koruma maksadıyla yük verme bir süre ertelenmelidir. ${ }^{[7]}$

\section{Nörolojik Yaralanma}

Nörovasküler yaralanmaların daha çok kapalı kama osteotomi tekniğinde görüldüğü söylenmektedir. En sık olarak ise peroneal sinir yaralanmaları görülmektedir. ${ }^{[3]}$ Daha çok lateral kapalı kama YTO'da fibular osteotomi ile ilişkilidir. İnsidans \%20'lere kadar çıkabilmektedir. ${ }^{[12]}$ Wootton ve ark., 105 vakalık serilerinde hastaların \%20'sinde (21 hasta) motor ve duyu kaybı saptamış ve bunların \%50'sinin kalıcı olduğunu söylemiştir. ${ }^{[61]}$

Kapalı kama YTO ile ilgili bir derlemeye göre semptomatik peroneal sinir yaralanması \%3,3-11,9 arasında görülmektedir. Fakat EMG ile değerlendirildiğinde sinir hasar oranı \%27'lere kadar çıkabilmektedir. Bu yaralanmaların birçoğu geçici olsa da bazı yazarlar kalıcı defisitler kalabileceğini söylemektedirler. ${ }^{[5]}$

YTO sonrasında sinir yaralanmasının ana nedenleri olarak turnike kullanımına bağlı nöropraksi, sıkı bandaj, sargı veya alçı, kompartman sendromu, aşırı açısal düzeltme ve iyatrojenik gibi nedenler sayılabilir. ${ }^{\text {[20] }}$ Özellikle kompartman basıncının arttığı durumlarda (50 mmHg'ya kadar ve genellikle postoperatif 6-24 saat arasında maksimum) dren kullanılması bu komplikasyonu azaltabilir. ${ }^{[5]}$ Postoperatif peroneal sinire ait defisitler genellikle anterior kompartman basınç artışı ile ilişkili bulunmuştur. ${ }^{[12]}$ 
Birçok yazara göre sinir yaralanmasındaki en sık neden iyatrojenik olup, fibular osteotomi sırasında meydana geldiği bildirilmektedir. YTO sonrasında ekstensör hallusis longus kası en çok etkilenen kastır. Bazen bu kas derin peroneal sinirden tek bir dal alarak innerve olur. Bu ayrılma genellikle fibular stiloid çıkıntının (proçesin) 7-8 mm uzağında bulunur. Böyle durumlarda meydana gelen yaralanmalar kalıcı olabilmektedir. Diğer bir tehlike ise peroneal sinirin fibula boynu ile yakın ilişkisidir. Sinir fibula başının ortalama $4 \mathrm{~mm}$ posterolateralinden geçmektedir. Bu nedenle fibula başının yaklaşık $16 \mathrm{~cm}$ distalinden, fibula orta ve distal 1/3'ünün birleştiği yerden ayrı bir insizyon ile fibular osteotomi önerilmektedir. ${ }^{[5]}$

Chabok, gerek kapalı kama tekniğinin dezavantajlarından olan peroneal sinir arazı ve fibular osteotomi kaynamaması durumlarından kaçınmak gerekse de cerrahi zamanı ve kanamayı azaltmak için kapalı kama YTO yaparken fibula osteotomisi yerine uygun hastalarda proksimal tibiofibular eklem kapsülotomisini önermektedir. Otuz dört vakalık serisinde bu teknikle sadece bir hastada duyusal peroneal sinir semptomlarının ortaya çıktığını bildirmiştir. ${ }^{[62]}$

Shin ve ark., 63 yaşında bir kadın hastaya medial açık kama YTO yaparken osteotominin altındaki ilk distal delikten uzun bir K-teli ve 4,5 mm'lik bir kortikal "lag" vidası gönderimi sonrasında tibial sinir hasarı geliş̧tiğini söylemişlerdir. Hastada herhangi bir motor defisit olmadığını, ayak tabanında duyu kusuru meydana geldiğini belirtmişler. Açıklama olarak da özellikle osteotominin altındaki ilk delikten yerleştirilen geçici "lag" vidasının kompresyon sağlayabilmek için normalden uzun gönderildiğini ve buna dikkat edilmediği takdirde tibial sinir ve popliteal damarlarda hasar oluşabileceğini söylemişlerdir. Medial açık kamada bu tarz yaralanmalardan kaçınmak için uygun diz pozisyonu, uygun ekartör pozisyonu ve floroskopi altında kontrollü şekilde K-teli ve vidanın titizlikle yerleştirilmesi gerekmektedir. ${ }^{[63]}$

Jeong ve ark.'nın yayımladıkları bir vakada, 61 yaşında açık kama YTO yapılan hastada cerrahi sonrasında ayak başparmağında düşüklük meydana gelmiş ve elektrodiagnostik çalışmalar ile bu durumun derin peroneal sinir yaralanması sonucu ortaya çıktığı belirtilmiştir. ${ }^{[64]}$ Bunun sebebi olarak da posterolateral bölgeden çıkmış olan bir vida gösterilmiş, cerrahi sonrası 3. haftada vida daha kısası ile değiştirilmiştir. Postoperatif 9. ayda motor ve duyu kaybı tamamen geri dönmüştür. ${ }^{[64]}$ Açık kama YTO'nun başlıca avantajlarından biri olarak düşük peroneal sinir yaralanma riski gösterilse de özellikle delme ve vidalama sırasında tibia posterolateraline dikkat edilmelidir.
Dikkatli bir cerrahi teknik, özellikle tibiofibular kapsül diseksiyonu sırasında künt ekartörlerin kullanımı oldukça önemlidir. ${ }^{[12]}$

\section{Kaynamama / Gecikmiş Kaynama}

Gecikmiş kaynama veya kaynamama insidansı literatürde farklı oranlarda olmakla beraber \%0-14 arasında değişebilmektedir. Kaynamama riskini azaltan faktörler olarak; karşı korteks kırığının önlenmesi, periosteal menteşe noktasının kalması, geniş ve düz kemik kesileri, kesi sırasında termal nekrozun önlenmesi ve güvenli fiksasyon sayılabilir. ${ }^{[20]}$ Ayrıca kaynamama için risk faktörü olarak medial açık kama YTO sırasında geniş derecelerde korreksiyon, sigara ve yetersiz fiksasyon sayılabilmektedir. ${ }^{[2]}$

Açık kama osteotomisinde daha sık, kapalı kama sonrasında daha az sıklıkta görülmektedir. Bunun nedeni kapalı kamada iki metafizyel kansellöz yüzeyin birbiri ile iyi temas etmesidir. Fakat yine de \%1-5 arasında kaynamama oranı kapalı kama tekniğinde literatürde bulunmaktadır. ${ }^{[5]}$ Açık kama tekniğinde ara bölgeye greft gerekebilir. Ayrıca fragmanların stabil fiksasyonu oldukça önemlidir. Geniş açısal korreksiyonlar, medial distraksiyon plak tekniği için kaynamama riski nedeniyle rölatif kontrendikasyon oluşturabilmektedir. Hastanın sigara içme ve diyabet gibi durumları dikkatle değerlendirilmelidir. Fizik muayene ve görüntüleme yöntemleri ile kaynamama/gecikmiş kaynama tanısı konulabilir. Tedavide psödoartroz bölgesinin rezeksiyonu, greftleme ve rijit fiksasyon seçenekleri kullanılabilir. ${ }^{[12]}$ Eğer sonrasında da kaynama sağlanamazsa artroplasti seçenek olarak düşünülebilir. [7]

Gecikmiş kaynama insidansı \%4-8,5 oranlarında görülebilmektedir. Özellikle osteotominin tibial tüberkülün distalinden yapılması sıklığı arttırmaktadır. Çünkü metafiz altının iyileşme potansiyeli daha düşüktür. ${ }^{[7]}$

\section{Enfeksiyon}

YTO sonrası enfeksiyon açısından literatür sınırlıdır. Enfeksiyon tanısı için net olarak bir tanım veya tanı kriteri bulunmamaktadır. Neden olan organizmalar ve standart tedavi protokolü de net olarak belli değildir. ${ }^{[13]}$

Kapalı kamada enfeksiyon oranlarının \%0,8-10,4 arasında değiştiği görülmektedir. ${ }^{[5]}$ Eksternal fiksatör kullanılan tekniklerde daha sık karşılaşııı. Çivi (Pin) ile ilişkili enfeksiyonlar \%25-50 oranlarına çıkabilmektedir. Septik artrit, osteomiyelit gibi daha ciddi enfeksiyonlar daha nadir olarak görülse de ileride kurtarıcı cerrahi olabilecek artroplasti operasyonlarını riske atabilir. ${ }^{[12]}$ 
Anagnostakos ve ark.'nın ${ }^{[13]}$ yaptıkları analizde toplamda 2026 hasta ve $2210 \mathrm{diz}$ incelenmiş. Pin ile ilişkili enfeksiyon oranları çalışmalarda \%2-71 oranlarında saptanmış. Yüzeyel enfeksiyonlar \%1-9 oranında, derin enfeksiyonlar ise \%0,5-4,7 oranında konu edilmiş. ${ }^{[13]}$ Oblik cilt insizyonu, sigara içimi ve bir günlük hastaneye yatış, enfeksiyon ile ilişkili bulunan parametreler olmuş. Osteotomi tipi, implant tipi, operasyon zamanı, turnike zamanı, antibiyotik profilaksisi ise enfeksiyon üzerinde anlamlı bir etki yapmayan parametreler olarak açıklanmış. Bunun yanı sıra yaş, cinsiyet, VKi, hastanın komorbiditeleri ve cerrahi endikasyon gibi parametreler izole enfeksiyon komplikasyonu açısından araştırılmamış genel komplikasyon ile ilişkisi değerlendirilmiş. il ginç olarak analize alınan bir çalışmada bir gün hastaneye yatan hastalarda çivi bölgelerinde $S$. aureus görülme ihtimali daha yüksek saptanmış. Sonuç olarak ise daha net ve güvenilir bilgiler için bu konuda geniş çok merkezli çalışmalara ihtiyaç olduğu söylenmiştir.

Reischl ve ark.110 YTO'da dört enfeksiyon bildirmişlerdir. Bunların hepsinde de oblik bir insizyon olduğu saptanmıştır ve istatistiksel anlamlı bulunan tek faktör bu olmuştur. Bazı yazarlar klasik paramedian longitudinal cilt insizyonu yerine daha iyi bir yaklaşım için oblik insizyonu savunmaktadır. Bunun dışında turnike kullanım zamanı ve enfeksiyon oranları arasında korelasyon saptanmamıştır. ${ }^{[65]}$

VKi, birçok ortopedik ve travmatik prosedürde enfeksiyon için risk faktörü iken YTO sonrası enfeksiyonun VKi ile ilişkisini gösteren çalışma sayısı oldukça azdır. Fakat VKI'nin YTO sonrası kaynamama için risk faktörü olduğunu gösteren yayınlar vardır. ${ }^{66]}$

Spahn, açık kama prosedürlerinde enfeksiyon komplikasyonunun yerleştirilen sentetik kemik greftleri ile ilişkili olduğunu söylemiştir. Dolayısıyla $12^{\circ}$ 'den fazla korreksiyon yapılan osteotomilerde boşluğun doldurulmasını önermiştir. ${ }^{[32]}$

Smith ve ark.'nın yaptıkları meta-analizde ise kapalı ve açık kama arasında enfeksiyon açısından anlamlı bir fark bulunmamıştır. Bunun yanı sıra (DVT), peroneal sinir arazı, kaynamama ve artroplastiye revizyon açısından da anlamlı bir fark saptanmamıştır. ${ }^{[67]}$

Steril şartlara saygın cerrahi tekniğe dikkat edilmelidir, profilaktik antibiyotik unutulmamalı ve eksternal fiksatör tekniğinde pin dibi bakımları özenle yapılmalıdır. Eritrosit sedimentasyon hızı, C-Reaktif Proteini, beyaz küre sayısı, ateş, eritem, ısı artışı, şişlik gibi bulgular ve pozitif kültürler ile enfeksiyon tanısı klasiktir. Çivi ile ilişkili enfeksiyonlar genellikle yüzeyel olduğundan, çivi dibi bakımı ve sistemik antibiyotik tedavisine sıklıkla cevap vermektedir. Derin enfeksiyonlarda ise yıkama ve debridman gerekebilir. ${ }^{[12]}$ Derin enfeksiyonlarda eğer greft kullanıldıysa greftin ve osteosentez materyalinin çıkarılması gerekebilir. Haliyle eksternal fiksatör tedavisi bu durumlarda devreye girebilir. ${ }^{[3]}$

Literatürde enfeksiyon yönetimi ile ilgili birçok seçenek (opsiyon) bulunmaktadır. Yukarıdaki metodların dışında çivi çıkarımı, derin enfeksiyonlarda revizyonlar, erken implant çıkarımı ve antibiyotik emdirilmiş çimento boncukları gibi seçenekler de kullanılabilir. Fakat komplikasyonları tedavi ederken korreksiyonda da kayıplar görülebilmektedir. ${ }^{[13]}$

Enfeksiyona bağlı kaynamamaların tedavisi ise daha zordur. Debridman sonrası internal fiksasyon cihazları kullanmak enfeksiyonun yüksek rekürrens riskinden dolayı uygun olmamakta, proksimal tibianın osteopenik, ya da fragmante olması, çivi yolu (pin trakt) enfeksiyon riskinin yüksek olması gibi nedenlerden dolayı eksternal fiksasyon bazı durumlarda sorunlu olabilmektedir. Bu gibi durumlarda Karatosun ve ark. ${ }^{68]}$ iki basamaklı bir prosedür önermektedir. İlk aşamada kapsamlı bir debridman, implant ve enfekte dokunun çıkarımı yapılır. Diğer aşamaya kadar diz ekstansiyonda bir splint ile stabilize edilir ve sistemik antibiyotikler verilir. Enfeksiyon eradikasyonu sonrasında ise uzun stemli bir tibial komponent kullanılarak total diz artroplastisi yapılır. Bu tedavi sonrasında yazarlar herhangi bir inatçı enfeksiyon bildirmemişlerdir. ${ }^{[68]}$

\section{Kompartman Sendromu}

Kesin insidans net olarak bilinmemekle birlikte anterior kompartman basıncının YTO sonrası arttığı bilinmektedir. Eğer eş zamanlı olarak ligament rekonstrüksiyonu yapıldıysa risk daha da artabilmektedir. Dikkatli bir cerrahi teknik olası travma ve vasküler yaralanmanın önüne geçip kompartman sendromu riskini azaltabilir. Postoperatif uzun süre epidural ağrı kontrolünden, kompartman sendromunu maskeleyebileceğinden ötürü uzak durmak gerekir. Postoperatif kompartman sendromu açısından yakın takip ve şüphede fasyotomi yapılması oldukça önemlidir. ${ }^{12]}$

\section{Tromboembolizm}

Osteotomi sonrası DVT literatürde total diz artroplastisindekine benzer oranda görülebilmektedir. Ölümcül pulmoner emboli ise oldukça nadirdir. DVT profilaksisi erken ambulasyon, kompresyon çorabı, antikoagülanlarla yapılmalıdır. Postoperatif yüksek şüphede hastanın vital bulgularının yakın takibi, BT (Bilgisayarlı Tomografi) veya ventilasyon perfüzyon sintigrafisine, pulmoner emboliyi ekarte etmek için başvurulabilir. Çözüm olarak heparin, kumadin gibi antikoagülanlar ve vena cava inferior filtresi kullanılabilir. ${ }^{[12]}$ 
Kapalı kama osteotomisi ile ilgili bir derlemeye göre eklem replasmanına benzer şekilde derin ven trombozu insidansı \%2-5 arasında değişmektedir. Subklinik olanlar ve distalde olanlar da dahil edildiğinde oran $\% 41$ 'lere varabilmektedir. ${ }^{[5]}$

Motycka ve ark. YTO'daki ortalama tromboz oranını $\% 10,8$ olarak bulmuşlar ve turnike kullanımı ile anlamlı ilişki saptamamışlardır. En yüksek insidansın postoperatif ilk 3-4 günde görüldüğünü belirtmişlerdir. ${ }^{[69]}$

\section{Patella İnfera}

YTO ile ilişkili patella infera görülebilmektedir. Bu durum da ön diz ağrısına sebep olabilmekte ve ileride diz protezine dönüşü zorlaştırmaktadır. Lateral kapalı kamada, uzun süre immobilizasyona bağlı patellar ligament kontraktürü nedeniyle görülebilirken, medial açık kama tibiofemoral eklem çizgisini yükseltmektedir. Lateral kapalı kamada stabil internal fiksasyon ve agresif bir postoperatif mobilizasyon bu nedenle önerilmektedir. Fizik muayene ve radyografiler durumun saptanmasında faydalıdır. En son çözüm olarak da revizyon veya total artroplasti yapılabilmektedir. ${ }^{[12]}$

\section{Osteonekroz}

Proksimal tibial fragmanın çok ince kesilmesi veya ayrışmış bir kemik adası oluşturacak şekilde osteotominin ilerlemesi proksimal fragmanın kan akımını bozabilir. Proksimal fragmanın uygun kalınlıkta ve osteotomi apeksinin uzak kortekse uygun mesafede bırakılması önemlidir. Postoperatif ağrı, fizik muayene bulguları, radyografide skleroz, deformite, kollaps gibi bulgular osteonekroza işaret edebilir. Çözüm olarak greftleme, revizyon osteotomi veya total artroplasti yapılabilir. ${ }^{[12]}$

\section{Vasküler Yaralanma}

Yüksek tibial osteotomi sırasında popliteal arteryaralanma oranı literatürde $\% 0,4$ ile $\% 9,8$ arasında değişen oranlarda görülebilmektedir. Darnis ve ark.'nın yaptığı kadavra çalışmasında diz $90^{\circ}$ fleksiyonda tibial osteotomiyi testere ile yaparken tibia arka yüzeyine bir koruyucu yerleştirmişlerdir. Koruyucu lateralden, tibia ile direkt temas sağlayarak, periost altından yerleştirilmiş. Ardından anjiografi yapılarak popliteal arter ile uzaklıklar ölçülmüştür. Popliteal arter $90^{\circ}$ diz fleksiyonunda eklem çizgisinin $2 \mathrm{~cm}$ altında, posterior tibial korteksten ortalama $11,7 \mathrm{~mm}$ (10,2-12,8 mm) uzaklıkta saptanmıştır. Osilasyon gösteren testere ile bu mesafenin kısaldığı görülmüştür. Çalışma sonucunda vasküler yapıları korumak için tibiaya direkt temas eden bir koruyucu alet konulmasını önermişler. ${ }^{[70]}$
Efe ve ark. 199 kapalı kama osteotomisinde \%19 komplikasyon oranı bildirmiş ve bunların dokuzunun vasküler komplikasyon olduğunu söylemişlerdir (sekiz DVT, bir vasküler yaralanma). ${ }^{[71]}$ Bunun yanı sıra medial açık kama osteotomisinde de vasküler komplikasyonlar tanımlanmıştır.

Kim ve ark. popliteal arter varyasyonlarını tanımlamışlardır. Buna göre tip Ila'da anterior tibial arter diz seviyesinin üstünden ayrılmakta ve posterior tibial kortekse oldukça yakın yerleşim göstermektedir. ${ }^{\text {[2] }}$ Dolayısı ile yaralanmaya oldukça açıktır.

Sawant ve Ireland, yüksek tibial osteotomi komplikasyonu olarak anterior tibial arterin anterior rekürren dalının psödoanevrizmasını bildirmişlerdir. ${ }^{[73]}$ Kapalı kama osteotomisi yaptıkları hastasında anterior tibial arterin, proksimal tibiada kasların subperiosteal elevasyonu sırasında ya da fibula başının inferomedial kısmının eksizyonu sırasında yaralandığını savunmuşlardır. Özellikle tibianın lateral taraf diseksiyonu ve proksimal tibiofibular eklemin inferomedial bölgesinin diseksiyonunda dikkatli olunması gerektiğini söylemişlerdir. Yara kapanmasından önce turnikenin açılıp kanama odaklarının saptanması gerektiğini belirtmişlerdir. ${ }^{[73]}$

Bu komplikasyonları engellemek için genel öneri ekartörleri kemik ile temas edecek şekilde yerleştirmek ve osteotomiyi diz $90^{\circ}$ fleksiyonda iken yapmaktır. Literatürde farklı bilgiler olsa da fleksiyonda iken çoğunlukla popliteal arterin uzaklaştığı söylenmektedir. Fakat bu durum hastanın supin, lateral dekübit pozisyonundan ve damar mobilitesi gibi durumlarda değişebilmektedir. Bu nedenle fleksiyon pozisyonu tek başına damar zedelenmesinin olmaması için yetmemektedir. ${ }^{[74]}$ Zaidi ve ark. popliteal arterin diz $90^{\circ}$ fleksiyonda tam ekstansiyona göre posterior tibiaya daha çok yaklaşabildiğini göstermiştir. ${ }^{[75]}$

Sonuç olarak diz çevresi osteotomiler; bilgi, deneyim, teknik beceri, eğitilmiş rehabilitasyon takımı ve karar verebilme özellikleri ekseninde başarıyla uygulanmaktadır. Komplikasyonlar ise oluşabilecek vazgeçilmezler içinde değerlendirilmelidir.

\section{Teşekkür}

Katkılarından dolayı teşekkür ederiz:

Doç. Dr. Onur Bilge, Necmettin Erbakan Üniversitesi Meram Tıp Fakültesi, Ortopedi ve Travmatoloji Anabilim Dalı, Konya

Dr. Barış Can Kuzuca, Ufuk Üniversitesi Tıp Fakültesi, Ortopedi ve Travmatoloji Anabilim Dalı, Ankara

Doç. Dr. Hande Güney Deniz, Hacettepe Üniversitesi Sağlık Bilimleri Fakültesi, Fizyoterapi ve Rehabilitasyon Bölümü, Ankara 
Prof. Dr. Defne Kaya, Üsküdar Üniversitesi Sağlık Bilimleri Fakültesi, Fizyoterapi ve Rehabilitasyon Bölümü, İstanbul

Doç. Dr. Gazi Huri, Hacettepe Üniversitesi Tıp Fakültesi, Ortopedi ve Travmatoloji Anabilim Dalı, Ankara

\section{KAYNAKLAR}

1. Wylie JD, Jones DL, Hartley MK, Kapron AL, Krych AJ, Aoki SK, Maak TG. Distal Femoral Osteotomy for the Valgus Knee: Medial Closing Wedge Versus Lateral Opening Wedge: A Systematic Review. Arthroscopy 2016;32(10):2141-7. Crossref

2. Capella M, Gennari E, Dolfin M, Saccia F. Indications and results of high tibial osteotomy. Annals of Joint 2017;2(6). Crossref

3. Yılmaz M, Kaya İ, Demir B, Uğraş AA, Çetinus E. Osteoartritin artroplasti dışı cerrahi tedavi seçenekleri. TOTBID Derg 2010;9(4):203-12. http://www.akinugras.com/yayinlar/ D11.\%20Osteoartritin\%20artroplasti\%20d\%E2\%94\%80\%E2 \%96\%92s\%E2\%95\%A0\%C4\%9F\%E2\%94\%80\%E2\%96\%92\%20 cerrahi\%20tedavi\%20sec\%E2\%95\%A0\%C4\%9Fenekleri.pdf

4. Esenkaya I, Unay K, Akan K. Proximal tibial osteotomies for the medial compartment arthrosis of the knee: a historical journey. Strategies Trauma Limb Reconstr 2012;7(1):13-21. Crossref

5. Atrey A, Morison Z, Tosounidis T, Tunggal J, Waddell JP. Complications of closing wedge high tibial osteotomies for unicompartmental osteoarthritis of the knee. Bone Joint Res 2012;1(9):205-9. Crossref

6. Felson DT, Niu J, Gross KD, Englund M, Sharma L, Cooke TD, Guermazi A, Roemer FW, Segal N, Goggins JM, Lewis CE, Eaton C, Nevitt MC. Valgus malalignment is a risk factor for lateral knee osteoarthritis incidence and progression: findings from the Multicenter Osteoarthritis Study and the Osteoarthritis Initiative. Arthritis Rheum 2013;65(2):35562. Crossref

7. Vena G, D'Adamio S, Amendola A. Complications of osteotomies about the knee. Sports Med Arthrosc Rev 2013;21(2):113-20. Crossref

8. Cameron JI, McCauley JC, Kermanshahi AY, Bugbee WD. Lateral opening-wedge distal femoral osteotomy: pain relief, functional improvement, and survivorship at 5 years. Clin Orthop Relat Res 2015;473(6):2009-15. Crossref

9. Amendola A. Knee osteotomy and meniscal transplantation: indications, technical considerations, and results. Sports Med Arthrosc Rev 2007;15(1):32-8. Crossref

10. Willey M, Wolf BR, Kocaglu B, Amendola A. Complications associated with realignment osteotomy of the knee performed simultaneously with additional reconstructive procedures. lowa Orthop J 2010;30:55-60. https://www.ncbi.nlm.nih. gov/pmc/articles/PMC2958271/

11. Stride D, Wang J, Horner NS, Alolabi B, Khanna V, Khan $M$. Indications and outcomes of simultaneous high tibial osteotomy and $\mathrm{ACL}$ reconstruction. Knee Surg Sports Traumatol Arthrosc 2019;27(4):1320-31. Crossref

12. Koyonos L, Slenker N, Cohen S. Complications in brief: osteotomy for lower extremity malalignment. Clin Orthop Relat Res 2012;470(12):3630-6. Crossref

13. Anagnostakos K, Mosser P, Kohn D. Infections after high tibial osteotomy. Knee Surg Sports Traumatol Arthrosc 2013;21(1):161-9. Crossref
14. Trieb K, Grohs J, Hanslik-Schnabel B, Stulnig T, Panotopoulos J, Wanivenhaus A. Age predicts outcome of high-tibial osteotomy. Knee Surg Sports Traumatol Arthrosc 2006;14(2):149-52. Crossref

15. Floerkemeier $\mathrm{S}$, Staubli AE, Schroeter $\mathrm{S}$, Goldhahn $\mathrm{S}$, Lobenhoffer P. Outcome after high tibial open-wedge osteotomy: a retrospective evaluation of 533 patients. Knee Surg Sports Traumatol Arthrosc 2013;21(1):170-80. Crossref

16. Shoji $\mathrm{H}$, Insall J. High tibial osteotomy for osteoarthritis of the knee with valgus deformity. J Bone Joint Surg Am 1973;55(5):963-73. Crossref

17. Sherman SL, Thompson SF, Clohisy JCF. Distal Femoral Varus Osteotomy for the Management of Valgus Deformity of the Knee. J Am Acad Orthop Surg 2018;26(9):313-24. Crossref

18. Duivenvoorden T, Brouwer RW, Baan A, Bos PK, Reijman M, Bierma-Zeinstra SM, Verhaar JA. Comparison of closingwedge and opening-wedge high tibial osteotomy for medial compartment osteoarthritis of the knee: a randomized controlled trial with a six-year follow-up. J Bone Joint Surg Am 2014;96(17):1425-32. Crossref

19. Brouwer RW, Huizinga MR, Duivenvoorden T, van Raaij TM, Verhagen AP, Bierma-Zeinstra SM, Verhaar JA. Osteotomy for treating knee osteoarthritis. Cochrane Database Syst Rev 2014(12): CD004019. Crossref

20. Dowd GS, Somayaji HS, Uthukuri M. High tibial osteotomy for medial compartment osteoarthritis. Knee 2006;13(2):8792. Crossref

21. Song EK, Seon JK, Park SJ, Jeong MS. The complications of high tibial osteotomy: closing- versus opening-wedge methods. J Bone Joint Surg Br 2010;92-B(9):1245-52. Crossref

22. Coventry MB, Ilstrup DM, Wallrichs SL. Proximal tibial osteotomy. A critical long-term study of eighty-seven cases. J Bone Joint Surg Am 1993;75(2):196-201. Crossref

23. Sun H, Zhou L, Li F, Duan J. Comparison between closingwedge and opening-wedge high tibial osteotomy in patients with medial knee osteoarthritis: a systematic review and meta-analysis. J Knee Surg 2017;30(2):158-65. Crossref

24. Brouwer RW, Bierma-Zeinstra SM, van Koeveringe AJ, Verhaar JA. Patellar height and the inclination of the tibial plateau after high tibial osteotomy. The open versus the closed-wedge technique. J Bone Joint Surg Br 2005;87-B(9):1227-32. Crossref

25. El-Azab H, Glabgly P, Paul J, Imhoff AB, Hinterwimmer S. Patellar height and posterior tibial slope after open-and closed-wedge high tibial osteotomy: a radiological study on 100 patients. Am J Sports Med 2010;38(2):323-9. Crossref

26. Wang Z, Zeng Y, She W, Luo X, Cai L. Is opening-wedge high tibial osteotomy superior to closing-wedge high tibial osteotomy in treatment of unicompartmental osteoarthritis? A meta-analysis of randomized controlled trials. Int J Surg 2018;60:153-63. Crossref

27. Ducat A, Sariali E, Lebel B, Mertl P, Hernigou P, Flecher X, Zayni R, Bonnin M, Jalil R, Amzallag J, Rosset P, Servien E, Gaudot $F$, Judet $T$, Catonné $Y$. Posterior tibial slope changes after opening- and closing-wedge high tibial osteotomy: a comparative prospective multicenter study. Orthop Traumatol Surg Res 2012;98(1):68-74. Crossref

28. Woodacre T, Ricketts M, Evans JT, Pavlou G, Schranz P, Hockings $\mathrm{M}$, Toms A. Complications associated with opening wedge high tibial osteotomy-a review of the literature and of 15 years of experience. Knee 2016;23(2):276-82. Crossref 
29. van den Bekerom MP, Patt TW, Kleinhout MY, van der Vis HM, Albers GH. Early complications after high tibial osteotomy: a comparison of two techniques. J Knee Surg 2008;21(1):6874. Crossref

30. Hoell S, Suttmoeller J, Stoll V, Fuchs S, Gosheger G. The high tibial osteotomy, open versus closed wedge, a comparison of methods in 108 patients. Arch Orthop Trauma Surg 2005;125(9):638-43. Crossref

31. Nelissen EM, van Langelaan EJ, Nelissen RG. Stability of medial opening wedge high tibial osteotomy: a failure analysis. Int Orthop 2010;34(2):217-23. Crossref

32. Spahn G. Complications in high tibial (medial opening wedge) osteotomy. Arch Orthop Trauma Surg 2004;124(10):64953. Crossref

33. Valkering KP, van den Bekerom MP, Kappelhoff FM, Albers $\mathrm{GH}$. Complications after tomofix medial opening wedge high tibial osteotomy. J Knee Surg 2009;22(3):218-25. Crossref

34. Niemeyer P, Schmal H, Hauschild O, von Heyden J, Südkamp NP, Köstler W. Open-wedge osteotomy using an internal plate fixator in patients with medialcompartment gonarthritis and varus malalignment: 3-year results with regard to preoperative arthroscopic and radiographic findings. Arthroscopy: J Arthrosc Relat Surg 2010;26(12):1607-16. Crossref

35. Chae DJ, Shetty GM, Wang KH, Montalban Jr ASC, Kim JI, Nha KW. Early complications of medial opening wedge high tibial osteotomy using autologous tricortical iliac bone graft and T-plate fixation. Knee 2011;18(4):278-84. Crossref

36. Ren Y-M, Duan Y-H, Sun Y-B, Yang T, Hou W-Y, Zhu R-S, Tian MQ. Opening-Wedge High Tibial Osteotomy Using Autograft versus Allograft: A Systematic Review and Meta-Analysis. J Knee Surg 2019. Crossref

37. Kuremsky MA, Schaller TM, Hall CC, Roehr BA, Masonis JL. Comparison of autograft vs allograft in opening-wedge high tibial osteotomy. J Arthroplasty 2010;25(6):951-7. Crossref

38. Gouin F, Yaouanc F, Waast D, Melchior B, Delecrin J, Passuti $\mathrm{N}$. Open wedge high tibial osteotomies: Calcium-phosphate ceramic spacer versus autologous bonegraft. Orthop Traumatol Surg Res 2010;96(6):637-45. Crossref

39. Jacobi M, Wahl P, Bouaicha S, Jakob RP, Gautier E. Distal femoral varus osteotomy: problems associated with the lateral open-wedge technique. Arch Orthop Trauma Surg 2011;131(6):725-8. Crossref

40. Stahelin T, Hardegger F, Ward JC. Supracondylar osteotomy of the femur with use of compression: osteosynthesis with a malleable implant. J Bone Joint Surg Am 2000;82(5):712-22. Crossref

41. Miller BS, Downie B, McDonough EB, Wojtys EM. Complications after medial opening wedge high tibial osteotomy. Arthroscopy 2009;25(6):639-46. Crossref

42. Brouwer R, Bierma-Zeinstra S, Van Raaij T, Verhaar JA. Osteotomy for medial compartment arthritis of the knee using a closing wedge or an opening wedge controlled by a Puddu plate: a one-year randomised, controlled study. J Bone Joint Surg Br 2006;88-B(11):1454-9. Crossref

43. Pilone C, Rosso F, Cottino U, Rossi R, Bonasia DE. Lateral Opening Wedge Distal Femoral Osteotomy for Lateral Compartment Arthrosis/Overload. Clin Sports Med 2019;38(3):351-9. Crossref

44. Han S-B, In Y, Oh KJ, Song KY, Yun ST, Jang K-M. Complications Associated With Medial Opening-Wedge High Tibial Osteotomy Using a Locking Plate: A Multicenter Study. J Arthroplasty 2019;34(3):439-45. Crossref
45. Magyar G, Toksvig-Larsen S, Lindstrand A. Hemicallotasis open-wedge osteotomy for osteoarthritis of the knee. Complications in 308 operations. J Bone Joint Surg $\mathrm{Br}$ 1999;81-B(3):449-51. Crossref

46. Adili A, Bhandari M, Giffin R, Whately C, Kwok DC. Valgus high tibial osteotomy. Comparison between an llizarov and a Coventry wedge technique for the treatment of medial compartment osteoarthritis of the knee. Knee Surg Sports Traumatol Arthrosc 2002;10(3):169-76. Crossref

47. Zhim F, Laflamme GY, Viens H, Saidane K, Yahia L. Biomechanical stability of high tibial opening wedge osteotomy: internal fixation versus external fixation. Clin Biomech (Bristol, Avon) 2005;20(8):871-6. Crossref

48. Haviv B, Bronak S, Thein R, Thein R. The results of corrective osteotomy for valgus arthritic knees. Knee Surg Sports Traumatol Arthrosc 2013;21(1):49-56. Crossref

49. Hernigou P, Giber D, Dubory A, Auregan JC. Safety of simultaneous versus staged bilateral opening-wedge high tibial osteotomy with locked plate and immediate weight bearing. Int Orthop 2020;44(1):109-17. Crossref

50. Lash NJ, Feller JA, Batty LM, Wasiak J, Richmond AK. Bone grafts and bone substitutes for opening-wedge osteotomies of the knee: a systematic review. Arthroscopy 2015;31(4):72030. Crossref

51. O'Connor A, Asaad P. Unusual presentation of acute pancreatitis following high tibial osteotomy. BMJ Case Rep 2019;12(2):e227438. Crossref

52. Türkmen I, Esenkaya I, Unay K, Akcal MA. Rhabdomyolysis after tourniquet use in proximal tibial osteotomy: a case report and review of the literature. Acta Orthop Traumatol Turc 2015;49(3):338-41. Crossref

53. Kettelkamp DB, Wenger DR, Chao EY, Thompson C. Results of proximal tibial osteotomy. The effects of tibiofemoral angle, stance-phase flexion-extension, and medial-plateau force. J Bone Joint Surg Am 1976;58(7):952-60. Crossref

54. Hernigou P, Medevielle D, Debeyre J, Goutallier D. Proximal tibial osteotomy for osteoarthritis with varus deformity. A ten to thirteen-year follow-up study. J Bone Joint Surg Am 1987;69(3):332-54. Crossref

55. Ellis RE, Tso CY, Rudan JF, Harrison MM. A surgical planning and guidance system for high tibial osteotomy. Comput Aided Surg 1999;4(5):264-74. Crossref

56. Kessler OC, Jacob HA, Romero J. Avoidance of medial cortical fracture in high tibial osteotomy: improved technique. Clin Orthop Relat Res 2002;395:180-5. Crossref

57. van Raaij TM, Brouwer RW, de Vlieger R, Reijman M, Verhaar JA. Opposite cortical fracture in high tibial osteotomy: lateral closing compared to the medial opening-wedge technique. Acta Orthop 2008;79(4):508-14. Crossref

58. Bae DK, Park CH, Kim EJ, Song SJ. Medial cortical fractures in computer-assisted closing-wedge high tibial osteotomy. Knee 2016;23(2):295-9. Crossref

59. Takeuchi R, Ishikawa H, Kumagai K, Yamaguchi Y, Chiba N, Akamatsu Y, Saito T. Fractures around the lateral cortical hinge after a medial opening-wedge high tibial osteotomy: a new classification of lateral hinge fracture. Arthroscopy 2012;28(1):85-94. Crossref

60. Stoffel K, Stachowiak G, Kuster M. Open wedge high tibial osteotomy: biomechanical investigation of the modified Arthrex Osteotomy Plate (Puddu Plate) and the TomoFix Plate. Clin Biomech (Bristol, Avon) 2004;19(9):944-50. Crossref 
61. Wootton J, Ashworth M, MacLaren C. Neurological complications of high tibial osteotomy--the fibular osteotomy as a causative factor: a clinical and anatomical study. Ann R Coll Surg Engl 1995;77(1):31-4. https://www.ncbi.nlm.nih. gov/pmc/articles/PMC2502526/pdf/annrcse01593-0041.pdf

62. Chabok HA. Midterm follow-up of closing wedge high tibial osteotomy with upper tibiofibular joint capsulotomy. Eur J Orthop Surg Traumatol 2019;29(5):1153-9. Crossref

63. Shin YS, Sim HB, Yoon JR. Tibial nerve neuropathy following medial opening-wedge high tibial osteotomy-case report of a rare technical complication. Eur J Orthop Surg Traumatol 2017;27(4):563-7. Crossref

64. Jeong JH, Chang MC, Lee SA. Deep peroneal nerve palsy after opening wedge high tibial osteotomy: A case report. Medicine (Baltimore) 2019;98(27):e16253. Crossref

65. Reischl N, Wahl P, Jacobi M, Clerc S, Gautier E, Jakob RP. Infections after high tibial open wedge osteotomy: a case control study. Arch Orthop Trauma Surg 2009;129(11):14837. Crossref

66. Meidinger G, Imhoff AB, Paul J, Kirchhoff C, Sauerschnig $M$, Hinterwimmer $S$. May smokers and overweight patients be treated with a medial open-wedge HTO? Risk factors for non-union. Knee Surg Sports Traumatol Arthrosc 2011;19(3):333-9. Crossref

67. Smith TO, Sexton D, Mitchell P, Hing CB. Opening- or closingwedged high tibial osteotomy: a meta-analysis of clinical and radiological outcomes. Knee 2011;18(6):361-8. Crossref

68. Karatosun V, Demir T, Unver B, Gunal I. A brief report on managing infected nonunion of a high tibial osteotomy in two stages: a case series involving seven knees. J Bone Joint Surg Br 2011;93-B(7):904-6. Crossref
69. Motycka T, Eggerth G, Landsiedl F. The incidence of thrombosis in high tibial osteotomies with and without the use of a tourniquet. Arch Orthop Trauma Surg 2000;120(34):157-9. Crossref

70. Darnis A, Villa V, Debette C, Lustig S, Servien E, Neyret P. Vascular injuries during closing-wedge high tibial osteotomy: A cadaveric angiographic study. Orthop Traumatol Surg Res 2014;100(8):891-4. Crossref

71. Efe T, Ahmed G, Heyse TJ, Boudriot U, Timmesfeld N, Fuchs-Winkelmann S, Ishaque B, Lakemeier S, Schofer MD. Closing-wedge high tibial osteotomy: survival and risk factor analysis at long-term follow up. BMC Musculoskelet Disord 2011;12(1):46. Crossref

72. Kim D, Orron DE, Skillman JJ. Surgical significance of popliteal arterial variants. A unified angiographic classification. Ann Surg 1989;210(6):776-81. Crossref

73. Sawant MR, Ireland J. Pseudo-aneurysm of the anterior tibial artery complicating high tibial osteotomy--a case report. Knee 2001;8(3):247-8. Crossref

74. Shetty AA, Tindall AJ, Qureshi F, Divekar M, Fernando KW. The effect of knee flexion on the popliteal artery and its surgical significance. J Bone Joint Surg Br 2003;85-B(2):21822. Crossref

75. Zaidi SH, Cobb AG, Bentley G. Danger to the popliteal artery in high tibial osteotomy. J Bone Joint Surg Br 1995;77$\mathrm{B}(3): 384-6$. Crossref 